\title{
The Intriguing Relation between Adult Minimum Wage and Child Labour
}

\author{
Kaushik Basu \\ Department of Economics \\ Cornell University \\ Ithaca, NY14853 \\ USA \\ and \\ Office of the Senior Vice President, Development Economics \\ The World Bank \\ 1818 H Street, N.W. \\ Washington, DC 20433 \\ USA \\ Email: kb40@cornell.edu
}

\begin{abstract}
Because most parents send their children to work when compelled by poverty, one would expect a rise in adult wage to lower child labor. However, if the rise in wage is achieved by a minimum wage law, its impact can be intriguing. It can, for instance, cause some adults to be unemployed and send their children to work, which in turn displaces more adult labour and sends more children to work. The paper solves this process and predicts the incidence of child labor. It shows that, for appropriate parametric configurations, child labour may fall or rise as the adult minimum wage is raised.
\end{abstract}

Pagehead Title: Adult Minimum Wage and Child Labour

Key words: minimum wage, child labour, unemployment

JEL classification: D10, J64

Acknowledgements: I have benefitted from seminars at Yale University, University of California at Berkeley, and Chicago University. For helpful comments and discussion I would like to thank two anonymous referees, Pranab Bardhan, Gary Becker, Alain de Janvry, Garance Genicot, Sajal Lahiri, Ayal Kimhi, Elizabeth King, Joseph Stiglitz and, especially, Elizabeth Sadoulet. 


\section{The Intriguing Relation between Adult Minimum Wage and Child Labour}

\section{Motivation}

There is now considerable evidence and some theoretical reason for believing that, in developing countries, improvement in the condition of adult workers results in the decline of child labour, since parents can then 'afford' to take their children out of the labour force (Goldin, 1979;

Horan and Hargis, 1991; Bonnet, 1993; Basu, 1999; Ray, 1999). Hence, one route to curbing child labor is to intervene in the adult labour market. However, much depends on how we intervene. If we adopt policies which raise the marginal productivity of adult workers, thereby raising wages and employment, all is well. On the other hand, the effect of a minimum wage legislation to bolster adult wages can be complicated. In some circumstances this may cause a drop in the incidence of child labour. But the analysis gets complex if the increase in wage causes adult unemployment to increase. This is because in most developing countries unemployment benefits are non-existent; so it is likely that adults who are unemployed will send their children to work. So a minimum wage can result in a higher supply of child labour. This will typically cause an increase in child employment, which, in turn, will cause further losses in adult employment and further additions to the supply of child labour. The full impact of this multiplier-like process can be large. This paper develops a model which helps us predict the net effect of such interventions.

While my focus here is on child labour, models of this kind are useful for analyzing the impact of minimum wage legislation or other kinds of wage rigidities on adult unemployment and job search (see 
Basu, Genicot and Stiglitz, 1999). There is a large empirical literature on this subject (see, for instance, Ashenfelter, 1980; Layard, Barton and Zabalza, 1980; Card and Krueger, 1995). This research is based on the presumption that children do not work, which is realistic for industrialized countries, but not for poor nations. According to ILO estimates, around 250 million children do full or part time work in the world, almost all of them in poor countries. When children are potential workers, standard results may undergo reversion, as this paper tries to show theoretically. It is hoped that this will inspire empirical work in developing countries ${ }^{1}$, which investigates the effect on child labour of legislation meant for the adult labour market.

\section{A Comment on Labour Standards}

The argument in this paper is of some significance in the context of the ongoing debate on international labour standards and the need for a 'social clause' in world trading arrangements. The case for trying to achieve minimal labour standards for workers the world over is unexceptionable. Workers should have the right to collective bargaining; children below a certain age, usually fifteen years, should not have to work; no one should be forced to work; workers should not be exposed to undue hazards; workers should be able to earn a living wage. All these and many other suggestions have been put

\footnotetext{
${ }^{1}$ Bardhan (1984) does study the effect of unemployment on the household labour supply decision in a developing country (India), but he pays no special attention to child labour.
} 
forward over the years and debated extensively (see, for instance, Bhagwati, 1995; Rodrik, 1996; Maskus, 1997, Basu, 1999a).

Troublesome questions arise as soon as we try to make these broad principles operational. Should trade sanctions be used to punish countries that violate some core labour standard? Would that lead to the standards issue being misused for protectionist purposes? Does the idea of labour standards run counter to the principle of comparative advantage?

The present paper touches on the debate on labour standards differently. It raises the question of consistency among labour standards. It is true that many of the standards support one another. For instance, if workers have the right to collective bargaining, they may themselves refuse to work under excessively hazardous conditions. However, there may be some standards, which, when upheld, tend to undermine other standards. One class of labour standards that is discussed under the label "survival rights" (see Portes, 1990) often includes a minimum wage for adult workers. What the present paper shows is that this right and the demand for the abolition of child labour--often made under the provision of "basic rights", may have a complicated relationship, with the achievement of one being made more difficult by the success of the other.

This paper is not on labour standards and no attempt is made here to stress one objective over another, but it draws attention to an issue that has received little attention--the inter-connections between different labour standards. In the light of the results in this paper one may question the wisdom of using minimum wage as a part of international labour standards. But my main concern is that, given that minimum wage laws are routinely used and have been discussed in the context of international labour standards, we need to analyze the effect of such laws. The problem is also analytically interesting 
because its impact on child labour is less than obvious.

\section{Model}

Consider an economy with $\mathrm{H}$ identical households. Each household has 1 adult and $\mathrm{m}$ children. Adult supply of labour is assumed to be inelastic; more specifically, adults always want to work. Concerning child labour, we will assume that, if the household income from non-child labour sources rises sufficiently high, the households will of their own accord withdraw the children from the labour force. For a general statement of this assumption and its justification, see Basu and Van (1998). In the present paper this assumption will be simplified as follows: [1] There is a critical number, s, such that children are sent to work if and only if adult wage drops below s.

[1] is easy to derive from a utility function if it is assumed that: [2] The labour market is such that a child can either work or not work (that is, there is no scope for part time work), [3] household norms are such that, all $\mathrm{m}$ children are either sent to work or none.

To see this, assume that the household maximizes the Stone-Geary utility function:

$$
u=\begin{array}{ll}
(c-s)(1-e), & \text { if } c \geq s \\
c-s, & \text { if } c<s,
\end{array}
$$

where u denotes household utility, $\mathrm{c}$ total household consumption, and e each child's work decision, with $\mathrm{e}=0$ being the decision not to work and $\mathrm{e}=1$ being the decision to work.

Denoting the wage for child labour prevailing on the market by $\mathrm{w}_{\mathrm{c}}$, the household's budget 
constraint is given by:

$$
\mathrm{c} \leq \mathrm{w}+\text { mew }_{\mathrm{c}}
$$

It is evident that if a household maximizes $\mathrm{u}$, subject to the above constraint, by choosing $\mathrm{c} \geq 0$ and $e \in\{0,1\},[1]$ will turn out to be true.

[2] and [3] are however unrealistic assumptions. The informal sector, where children usually work has a lot of flexibility and so it is possible for children to work a few hours each day (see, for instance, Grootaert and Patrinos, 1998). In other words, e can take fractional values. Moreover, parents are in reality free to send only some children to work. Can we allow for these possibilities and still derive [1]? The answer is yes, and this is shown at the end of this section.

Let us now assume that a child's labour and an adult's labour are two factors of the same kind. The difference is simply that a child produces a fraction $?(<1)$ of an adult's labour. It may be convenient to think of this in the following way. There is a factor called labour (or effective labour, for emphasis) and each adult produces 1 unit of labour, while each child produces ? units of labour. This being so, it is obvious that, whenever both children and adults work, the prevailing adult and child wages must satisfy the following condition:

$$
\mathrm{w}_{\mathrm{c}}=? \mathrm{w} .
$$

If this condition did not hold, firms could do better by substituting one kind of labour for another.

Given this simplifying assumption, it is clear that when adult wage is w, child wage must be ?w, and what a firm will care about is the total amount of labour it has. What this total is composed of, that is, how much adult labour and how much child labour, is unimportant to the firm. Hence, we could write the aggregate demand function for labour in the economy as follows: 


$$
\mathrm{D}=\mathrm{d}(\mathrm{w})
$$

where $\mathrm{D}$ is the aggregate labour demanded by all firms in the economy. We will assume that $\mathrm{d}^{\prime}(\mathrm{w})<0$. This demand curve is illustrated by the line marked D in Fig. 1.

From the description of households, above, it follows that the aggregate labour supply curve, as a function of the adult wage, is given by the step-shaped line marked $S$ in Fig. 1. Note that if w exceeds $\mathrm{s}$, only adults supply their labour. There being $\mathrm{H}$ adults in the economy, the labour supply is given by $\mathrm{H}$. If $\mathrm{w}$ drops below $\mathrm{s}$, the $\mathrm{mH}$ children in the economy are out searching for work. Since they provide ? units of labour each, the total supply of labour is given by $\mathrm{H}+$ ?mH.

\section{[Fig. 1 somewhere here.]}

The remainder of this section constructs a household utility function, which does not use assumptions [2] and [3] but nevertheless results in a supply curve like Fig. 1. What we need is a utility function that generates indifference curves of the kind shown by the unbroken lines in Fig. 2. This is a somewhat unusual figure. The vertical axis represents household income, and the horizontal axis the total amount of 'leisure' enjoyed by the household. This leisure is however normalized; that is, leisure is measured as the complement of the total effective labour that the household can supply. Thus if the adult does not work, the leisure gained is 1 , but if a child does not work the leisure gained is ?. This is not an assumption but simply a convenient way of representing leisure and work on the same axis. Hence, the maximum (normalized) leisure that a household can consume is given by ? $m+1$. The horizontal axis in Fig. 2 should be thought of as representing first the children's leisure (up to the point marked ?m) and then the adult's leisure.

[Fig. 2 somewhere here.] 
The lowest indifference curves are horizontal. Then as we move to higher indifference curves the segments to the right of ?m remain horizontal, but to the left become steeper. If the adult wage is s (and so by definition each unit of effective labour costs s) the budget constraint is given by the line $\mathrm{AB}$ and it is clear that the household is indifferent between supplying any amount of labour between ?m +1 and 1 (or, equivalently, buying any amount of leisure between 0 and ?m). By inspecting the figure it is evident that if wage rises above s, labour supply from each household will be 1 and if wage is below s labour supply from each household will be $? \mathrm{~m}+1$.

To describe the Fig. 2 mathematically, use L to denote the amount of normalized leisure consumed by the household (implying that the amount of labour supplied by the household is ?m +1 L). Choosing any number $\mathrm{de}(0,1)$ consider the following utility function:

$$
\mathrm{u}(\mathrm{c}, \mathrm{L})=\begin{aligned}
& \mathrm{c}, \quad \text { if } \mathrm{L} \geq ? \mathrm{~m} \text { or } \mathrm{c} \leq \mathrm{s}(1-\mathrm{d}) \\
& \{\mathrm{dc}+(? \mathrm{~m}-\mathrm{L}) \mathrm{s}(1-\mathrm{d})]\} /\{? \mathrm{~m}+\mathrm{d}-\mathrm{L}\}, \quad \text { otherwise }
\end{aligned}
$$

The second line of the utility function is simply a mathematical representation of the fact that the indifference curves in Fig. 2, above the line s(1-d) and to the left of ?m, are rays fanning out of the point $(? \mathrm{~m}+\mathrm{d}, \mathrm{s}(1-\mathrm{d})$

Maximizing this utility function, subject to the budget constraint,

$$
\mathrm{c} \leq \mathrm{w}(? \mathrm{~m}+1-\mathrm{L})
$$

yields a supply curve with property [1], which is illustrated in Fig. 1.

\section{Results}


Observe that in this model there can be more than one stable equilibria in the labour market. An economy can get caught in the 'bad' equilibrium, $\mathrm{E}^{\mathrm{B}}$, where adult wage is $\mathrm{w}^{\mathrm{B}}$ and child labour is high, even though a 'good' equilibrium, $\mathrm{E}^{\mathrm{G}}$, where adult wage is $\mathrm{w}^{\mathrm{G}}$ and children do not work, were available (see Fig. 1). My concern here is with the possibility of using minimum wage legislation to get out of the bad equilibrium. This is an important question because a direct ban on child labour is very difficult to implement. And though adult minimum wages are also hard to implement, most countries have such legislation already in place and some mechanism for implementing it. In addition, if such legislation makes it in the parents' interest to pull their children out of the labour force, then one may be able to get around the problem of monitoring child labour.

At first sight, it looks as if any legal minimum wage, $\underline{w}$, for adults, as long as it is strictly above s (see Fig. 1), will help the economy to move to $\mathrm{E}^{\mathrm{G}}$. But that is not true. The relation between adult minimum wage and child labour turns out to be more complicated, as I had indicated in Basu (1999), but not managed to fully work out. The aim of this essay is to push this line of enquiry to a close.

Consider first of all the case where government sets $\underline{w}$ at or above $\mathrm{w}^{\mathrm{G}}$. To analyse the effect of minimum wage legislation we need to distinguish between the case where

$$
? \mathrm{~m}<\mathrm{d}(\underline{\mathrm{w}}) / \mathrm{H}
$$

holds and where it does not. Since ? is likely to be small for work that requires skill, this condition is more likely to hold for skilled work. In reality? rises with the age of the child ${ }^{2}$ (a detail that we have

${ }^{2}$ Cain (1977) has calculated how in rural Bangladesh ? rises with age and reaches 1 by around the age of 13 years. 
ignored in our model). Therefore, since smaller children are usually employed in family farms, (3) is likely to be satisfied by family farms.

Let us first consider the case where (3) holds. How many adults will find employment? By looking at Fig. 1 and supposing that $\underline{w}$ is as shown, one may at first believe that $\mathrm{d}(\underline{\mathrm{w}})$ (shown in the figure by the line segment $\underline{w F}$ ) adults will find work. This is however not true. To see this let us use E to denote the number of adults who find employment. Then $\mathrm{H}$ - E adults are unemployed, which means that in $\mathrm{H}$ - E households the income earned by the adults will be zero. Therefore, the children from all these households will be looking for work. Hence, the aggregate supply of child labour is ?m(H - E). Given that the wage is $\underline{w}$, the aggregate demand for labour is $\mathrm{d}(\underline{\mathrm{w}})$. Since E adults find work, the demand for child labour will be $\mathrm{d}(\underline{\mathrm{w}})$ - E. Hence, there will be equilibrium in the child labour market if:

$$
? \mathrm{~m}(\mathrm{H}-\mathrm{E})=\mathrm{d}(\underline{\mathrm{w}})-\mathrm{E}
$$

Solving this for $\mathrm{E}$, and writing the solution as $\mathrm{E}^{*}(\underline{\mathrm{w}})$, we have:

$$
\mathrm{E}^{*}(\underline{\mathrm{w}})=[\mathrm{d}(\underline{\mathrm{w}})-? \mathrm{mH}] /(1-? \mathrm{~m})
$$

If $\mathrm{E}$ adults work, the incidence of child labour, as we just saw, is given by $\mathrm{m}(\mathrm{H}-\mathrm{E})$. Hence, if the legal minimum wage is $\underline{w}$, the amount of child labour in the economy, $\mathrm{C}(\underline{w})$ is given by $\mathrm{m}(\mathrm{H}$ $\left.\mathrm{E}^{*}(\underline{\mathrm{w}})\right)$. Using (4), we have:

$$
\mathrm{C}(\underline{\mathrm{w}})=\mathrm{m}[\mathrm{H}-\mathrm{d}(\underline{\mathrm{w}})] /(1-? \mathrm{~m})
$$

Since $\underline{w} \geq w^{G}, d(\underline{w})<H$. This coupled with (3), implies that $1-? m>0$. Hence, $C(\underline{w}) \geq 0$ and as $\underline{w}$ increases, $\mathrm{C}(\underline{\mathrm{w}})$ increases.

Proposition 1. If $\underline{w} \geq w^{G}$ and (3) is true, then a rise in $\underline{w}$ results in a rise in the incidence of child 
labour.

It is interesting to note that just as in standard textbook models, it is price that moves up and down to bring about equality in demand and supply, in our model it is the amount of adult employment, E, which adjusts till the point where demand for child labour is equal to the supply of child labour. Keeping this in mind we can draw the demand and supply of child labour as a function of E. These are shown in Fig. 3. These curves are understood by following the reasoning preceding equation (4). The position of these curves depends on $\underline{w}$ (in addition, they are drawn under the assumption that $\underline{w} \geq w^{G}$ ) and so the curves will shift as $\underline{w}$ is changed.

[Fig. 3 somewhere here.]

In the case illustrated in Fig. 3, which follows from the assumptions $\underline{w} \geq w^{G}$ and (3), the equilibrium adult employment, $\mathrm{E}^{*}(\underline{\mathrm{w}})$, and therefore the equilibrium child labour, $\mathrm{C}(\underline{\mathrm{w}})$, are, in a sense, stable: Observe first that the supply curve necessarily cuts the demand curve from above. Now, suppose, for the moment, that $\mathrm{E}$ adults, where $\mathrm{E}<\mathrm{E}^{*}(\underline{\mathrm{w}})$, have found jobs. Then the demand for child labour will exceed the supply of child labour. Hence, employers will end up employing more adults. Thus $\mathrm{E}$ will move up, towards $\mathrm{E}^{*}(\underline{\mathrm{w}})$. One can do a similar exercise starting with an $\mathrm{E}$ greater than $\mathrm{E}^{*}(\underline{\mathrm{w}})$.

As remarked earlier, though at the minimum wage, $\underline{w}$, the supply of adult labour exceeds the demand for labour, more adults get unemployed than the extent of the excess supply. In Fig. 1, let the minimum wage be at $\underline{w}$. Then the supply of labour is given by the line segment $\underline{w} \mathrm{~K}$ and the demand for labour is given by the segment $\underline{w F}$. It may therefore appear that $\underline{w} F$ adults will find employment, with 
FK being unemployed. But that is not so. The fact of FK adults being unemployed will send the children of their household out in search of work. This will displace some more adults from their work, sending some more children out in search of work, and so on. The employment level of adults which finally occurs, $\mathrm{E}^{*}(\underline{\mathrm{w}})$, must therefore be less than the line segment $\underline{\mathrm{wF}}$ in Fig. 1. A statement and proof of this proposition follows.

Proposition 2. If $\underline{w}>w^{G}$ and (3) is true, then adult employment is less than the demand for labour. (4) implies: $(1-? \mathrm{~m}) \mathrm{E}^{*}(\underline{\mathrm{w}})=\mathrm{d}(\underline{\mathrm{w}})-? \mathrm{mH}<\mathrm{d}(\underline{\mathrm{w}})-? \mathrm{md}(\underline{\mathrm{w}})$, since $\mathrm{d}(\underline{\mathrm{w}})<\mathrm{H}$. It follows that $\mathrm{E}^{*}(\underline{\mathrm{w}})<\mathrm{d}(\underline{\mathrm{w}})$, which completes the proof of proposition 2 .

Next we turn to what would happen if (3) did not hold. So assume

$$
? \mathrm{~m} \geq \mathrm{d}(\underline{\mathrm{w}}) / \mathrm{H}
$$

If (5) were true, then the minimum wage would have quite a dramatic effect (we are continuing with the case where the minimum wage is set at or above $\mathrm{w}^{\mathrm{G}}$ ). To see this define $\mathrm{w}^{*}$ implicitly by

$$
\mathrm{d}\left(\mathrm{w}^{*} / ?\right)=? \mathrm{mH}
$$

This and (5) imply:

$$
\underline{\mathrm{w}} \geq \mathrm{W} * / ?
$$

It is now easy to check that there is an equilibrium in which child wage is $\mathrm{w}^{*}$, no adults are employed and all the children work. To see this observe that adults cannot undercut the child wage because of (7). Hence, if child wage is $\mathrm{w}^{*}$, no adult will find work. Hence, all the $\mathrm{mH}$ children in the economy will be looking for work; and labour supply from children will equal ?mH. Therefore, by (6), 
the supply of child labour will be equal to demand. So what we have established may be summed up as follows.

Claim 1. If $\underline{\mathrm{w}} \geq \mathrm{w}^{\mathrm{G}}$ and (3) is false, then there is an equilibrium in which all adults are unemployed and all children work.

Let us now turn to the case where the legal minimum wage is set below $\mathrm{w}^{\mathrm{G}}$. Let us consider $\underline{\mathrm{w}}$ $\in\left(\mathrm{s}, \mathrm{w}^{\mathrm{G}}\right)$. This is quite a real possibility. Since $\mathrm{s}$ is the level of adult wage below which households find it necessary to send their children to work, government may well consider setting a minimum wage floor above s.

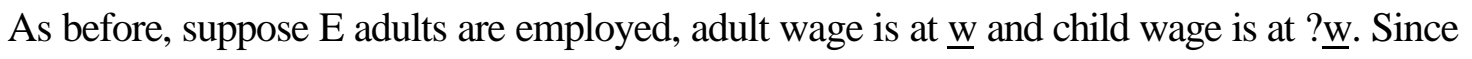
adult wage is above s, all households where the adult finds work will not send their children to work; other households will. Hence, $\mathrm{m}(\mathrm{H}$ - E) children look for work and so the supply of labour by children is given by $? \mathrm{~m}(\mathrm{H}-\mathrm{E})$. The demand for labour from children is $\mathrm{d}(\underline{w})$ - E. Hence, as before, the child labour market is in equilibrium if $? \mathrm{~m}(\mathrm{H}-\mathrm{E})=\mathrm{d}(\underline{w})-\mathrm{E}$. Thus the equilibrium employment of adults is given by (4).

Consider first the case where $? \mathrm{~m}>\mathrm{d}(\underline{\mathrm{w}}) / \mathrm{H}$. Then $? \mathrm{~m}>1$, since $\mathrm{d}(\underline{\mathrm{w}})>\mathrm{H}$. It follows from (4), that $\mathrm{E}^{*}(\underline{\mathrm{w}}) \in[0, \mathrm{H}]$. Hence, we have an equilibrium in which wage settles at $\underline{\mathrm{w}}$ and both adults and children work.

Proposition 3. If $\underline{w} \in\left(s, w^{G}\right)$ and (3) is violated, then there exists an equilibrium where wage settles at 
$\underline{w}$ and both adults and children work.

This is, at first sight, a perplexing. Even though there is a market-clearing wage above the minimum wage (since $\mathrm{w}^{\mathrm{G}}>\underline{\mathrm{w}}$ ), a new equilibrium gets created once a minimum wage is implemented. Though normally at that wage demand for labour would have exceeded supply, now, the fact of there being a minimum wage creates conditions for labour supply to increase (with children joining the labour market) up to the point where demand is equal to supply.

The utility function at the end of section 3 is an example of where this can happen. One can also think of intuitive reasons for it. If a household is poor because the adult wage is low or the adult is unemployed, the children may have to be sent out to work a certain amount. But this could jeopardize the child's schooling prospect and, once this happens, the opportunity cost of child labour falls and so the supply of child labour increases. Goldin (1979) has, in the context of the late nineteenth century Philadelphia, discussed the response of a child's labour and schooling to the father's unemployment; and her findings are consistent with the above.

Yet another route to explain this paradoxical result is to note that the children's supply response is somewhat like an 'added worker effect'. To model this entails a much more elaborate setting than the one described here. The idea is that, if there is a certain amount of unemployment expected to prevail in the labour market, some risk-averse households, fearing that the main breadwinner may lose his or her job, may send out more workers than they would have at that wage if the there was assured of fullemployment in the economy. That is the line followed by Basu, Genicot and Stiglitz (1999).

When the hypothesis of proposition 3 is true, there is another possible equilibrium, in which 
adults are fully displaced by the children. Define w' to be such that $\mathrm{d}\left(\mathrm{w}^{\prime} / \mathrm{l}\right)=? \mathrm{mH}$. Hence, $\mathrm{d}\left(\mathrm{w}^{\prime} /\right.$ ? $)>$ $\mathrm{d}(\underline{\mathrm{w}})$. It follows that $\mathrm{w}^{\prime} / ?<\underline{\mathrm{w}}$. So, now suppose that children get a wage of w'; all firms will prefer children; adults are unable to undercut the wage because of the minimum wage legislation; and $\mathrm{d}(\mathrm{w} /$ ? $)=$ ?mH implies that demand for child labour is equal to the supply. So we have an equilibrium, which may be summed up as follows.

Claim 2. If $\underline{\mathrm{w}} \in\left(\mathrm{s}, \mathrm{w}^{\mathrm{G}}\right)$ and (3) is false, then there is an equilibrium in which all adults are unemployed and only children work.

Claims 1 and 2 may now be combined to state the following proposition.

Proposition 4. If $\underline{w}>s$ and (3) is false, then there is an equilibrium in which all adults are unemployed and only children work.

Finally, while still assuming that $\mathrm{w}^{\mathrm{G}}>\underline{\mathrm{w}}>\mathrm{s}$, let us consider what happens if $\mathrm{d}(\underline{\mathrm{w}}) / \mathrm{H}>$ ?m. It can be verified that either $\mathrm{E}^{*}(\underline{w})$ is negative $($ if $? \mathrm{~m}>1)$ or greater than $\mathrm{H}($ since $\mathrm{d}(\underline{w})>\mathrm{H})$. Since both those are infeasible, it follows that there is no equilibrium in which adult wage is at $\underline{\mathrm{w}}$ and adults work. So this is the case where the good equilibrium is unequivocally reached, to wit, adult wage rises to $\mathrm{w}^{\mathrm{G}}$ and only adults work. Hence, in this case the minimum wage law would certainly work.

What proposition 4 and the above paragraph say is quite interesting. Suppose a minimum wage is imposed somewhere above $\mathrm{s}$ and below $\mathrm{w}^{\mathrm{G}}$ in Fig. 1. At first sight it appears that since there were two equilibria in the labour market, $\mathrm{E}^{\mathrm{G}}$ and $\mathrm{E}^{\mathrm{B}}$, and the latter is no longer feasible, the only possible 
equilibrium is $\mathrm{E}^{\mathrm{G}}$. What we have just established is that, though $\mathrm{E}^{\mathrm{G}}$ may well be achieved, the very imposition of a minimum wage law, can bring into existence a new equilibrium --one in which the wage settles at $\underline{w}$ and child labour expands to the maximum possible in the economy, while adults are unemployed $^{3}$. Hence, if one is using legislative action in an economy with multiple equilibria, it seems safer to use a ban on child labour, instead of the more indirect method of setting laws regarding the level of wage. ${ }^{4}$

\section{Interpretation}

Observe that minimum wage legislation tends to backfire most seriously (the case of Proposition 4) when (3) is false, that is, when ?m is large. Indeed note that our results in general are very sensitive to the magnitude of ?m. What does this variable represent? As it turns out this is quite an economically significant variable. It denotes the amount of effective labour that the children of a single household can supply.

In a modern economy, typically, fertility is low, and so $\mathrm{m}$ will be small. Also, jobs being more skilled, children are a poorer substitute for adults; so ? happens to be small. It is conceivable that for

${ }^{3}$ The simplicity of the model makes the result look more extreme than it will be in reality. In reality the labour market is usually segmented and our model could be thought of as pertaining to the unskilled end of the segments. Viewed in this way, what the result says is that children will tend to replace adults in the bottom end (skill-wise) of the labour market.

${ }^{4}$ Of course, one can use a combination of minimum wage laws for both adults and children to ensure that children do not work, but surely that is more cumbersome a route than simply declaring child labour illegal. 
even the least-skilled of computing jobs, for instance, word-processing, ? will be very small. On the other hand, for certain kinds of labour-intensive work, such as making hand-knotted carpets, ? will be quite high (see Levison et al, 1998). Hence, ?m will tend to be small in a modern, industrialized economy, and large in a developing economy. In other words, (3) is more likely to be violated and so proposition (3) more likely to be relevant in a poor country. Therefore, the suggestion of using a minimum wage legislation in developing countries as a form of international labour standard has the risk of exacerbating the problem of child labour. 


\section{References}

Ashenfelter, O. (1980), 'Unemployment as disequilibrium in a model of aggregate labour supply', Econometrica, vol. 48.

Bardhan, P.K. (1984), Land, Labour and Rural Poverty, Columbia University Press, New York.

Basu, K. (1999), 'Child labour, cause, consequence and cure, with remarks on international labour standards', Journal of Economic Literature, forthcoming.

Basu, K. (1999a), 'International labour standards and child labour', Challenge, forthcoming.

Basu, K., Genicot, G. and Stiglitz, J. E. (1999), 'Household labour supply, unemployment, and minimum wage legislation', Policy Research Working Paper, No. 2049, The World Bank.

Basu, K. and Van, P. H. (1998), 'The economics of child labour', American Economic Review, vol. $88,412-27$.

Bhagwati, J. N. (1995), 'Trade liberalization and 'Fair Trade' demands: Addressing the environment and labour standards issue', World Economy, vol. 18, 745-59.

Bonnet, M. (1993), 'Child labour in Africa', International Labour Review, vol. 132, 371-89.

Cain, M. T. (1977), 'The economic activities of children in a village in Bangladesh', Population and Development Review, vol. 3, 201-27.

Card, D. and Krueger, A. (1995), Myth and Measurement: The New Economics of Minimum Wage, Princeton University Press, Princeton.

Goldin, C. (1979), 'Household and market production of families in a late nineteenth-century American town', Explorations in Economic History, vol. 16, 111-31.

Grootaert, C. and Patrinos, H. (1998), The Policy Analysis of Child Labour: A Comparative Study, manuscript, World Bank.

Horan, P. M. and Hargis, P. G. (1991), 'Children's work and schooling in the late nineteenth- century family', American Sociological Review, vol. 56, 583-96.

Layard, P. R. G., Barton, M. and Zabalza, A. (1980), 'Married women's participation and hours', Economica, vol. 47, 51-72. 
Levison, D. et al (1998), 'Is child labour really necessary in India's carpet industry?', in Anker, Richard et al (eds.), Economics of Child Labour in Selected Industries of India, Hindustan Publishers, New Delhi, forthcoming.

Maskus, K. (1997), 'Should core labour standards be imposed through international trade policy?', Policy Research Working Paper, No. 1817, The World Bank.

Portes, A. (1990), 'When more can be less: Labour standards, development, and the informal economy', in Labour Standards and Development in the Global Economy, U.S. Department of Labour, Washington, DC.

Ray, R. (1999), 'Child labour, child schooling and their interaction with adult labour:The empirical evidence and some analytical implications', mimeo: Hobart University.

Rodrik, D. (1996), 'Labour standards in international trade: Do they matter and what do we do about them?', Policy Essay, No. 20, Overseas Development Council, Washington, DC. 